\title{
Actin-Like Protein 6A
}

National Cancer Institute

\section{Source}

National Cancer Institute. Actin-Like Protein 6A. NCI Thesaurus. Code C157275.

Actin-like protein 6A (429 aa, $47 \mathrm{kDa}$ ) is encoded by the human ACT L6A gene. This protein plays a role in the regulation of both chromatin remodeling and histone acetyltransferase activity. 